\title{
Morbidity and mortality rates for childhood cancer in Argentina. 2006-2008
}

\author{
Celine Jeanne Aurelie Pujol, M.D. ${ }^{a}$, Carola Leticia Bertone, M.D. and B.S. ${ }^{a}$, \\ Laura Débora Acosta, B.S. ${ }^{a}$
}

\begin{abstract}
Introduction. Childhood cancer is a serious public health problem in any country given the large number of years of life lost in an early manner.

Objective. To describe morbidity and mortality rates for cancer in Argentinean children and adolescents younger than 15 years old in the 2006-2008 three year period.

Method. Specific mortality rates and incidence rates per million inhabitants were analyzed in children and adolescents younger than 15 years old by type of tumor and gender. Vital statistics data were used based on the databases provided by theStatistics and Health Information Department of the Ministry of Health of Argentina and the population of 0-14 year old children estimated by the National Statistics and Censuses Institute of Argentina (Instituto Nacional de Estadísticas y Censos, INDEC). In relation to morbidity data, the information published by the Argentine Hospital Oncopediatric Registry (Registro Oncopediátrico Hospitalario Argentino, ROHA) was used.

Results. Mortality rate from malignancies was 43.8 per million (3.5\% of total deaths in this age group) and the incidence rate was 123.7 per million. Leukemia had the highest specific mortality rate (14.9 per million), followed by tumors in the central nervous system (12.7 per million). The highest incidence rates were also registered for these tumors (45.2 and 15.5 per million, respectively).

Conclusions. Mortality from malignancies accounted for $3.5 \%$ of deaths in children and adolescents younger than 15 years old in Argentina. Leukemia and tumors in the central nervous system had the highest specific mortality and incidence rates.

Key words: childhood mortality, morbidity, malignancies.
\end{abstract}

a. Culture and Society Research and Study Center. (Centro de Investigaciones y Estudios sobre Cultura y Sociedad, CIECS). CONICET Executive Unit. Universidad Nacional de Córdoba.

E-mail Address:

B.S. Laura D. Acosta: laudeac@hotmail.com

Conflict of Interest: None.

Received: 2-8-2013 Accepted: 7-16-2013 http:/ / dx.doi.org/10.5546/aap.2014.eng.50

\section{INTRODUCTION}

The reduction of the relative burden of infectious diseases and malnutrition, and the significant advances in newborn infant care account for the relevance that childhood cancer is acquiring, in spite of its low occurrence. ${ }^{1}$

Childhood cancer is a serious public health problem in any country given the high number of years of life lost in an early manner. In developed countries, child mortality from malignancies has decreased, essentially thanks to the advances in cancer diagnosis and management; ${ }^{2}$ therefore, cancer mortality can be taken as an indicator of healthcare quality. ${ }^{3}$ In Latin American countries, such rates are higher and mortality does not appear to be reducing, although certain stability has been observed. $^{2}$

According to data provided by the National Ministry of Health, ${ }^{4}$ in Argentina cancer is the second leading cause of death in the 5-24 year old population, after external causes.

In relation to morbidity, data are provided by the Argentine Hospital Oncopediatric Registry (Registro Oncopediátrico Hospitalario Argentino, ROHA), an organization that surveys new cases of cancer in Argentinean children younger than 15 years old. As per the ROHA's data, the raw incidence rate for Argentina was 124 per million children and adolescents younger than 15 years old between 2000 and 2008, and the specific mortality rate from malignancies for individuals in this age range was 3.6 per million in $2008 .^{5}$

The objective of this study was to describe morbidity and mortality rates for cancer in Argentinean children and adolescents younger than 15 years old in the 2006-2008 three year period.

\section{METHOD}

This was a descriptive study based on secondary data sources: the Statistics and Health Information Department (Dirección de Estadísticas e Información de Salud, DEIS) of the Ministry of Health of Argentina, the National Statistics and Censuses 
Institute of Argentina (Instituto Nacional de Estadisticas y Censos, INDEC), and the ROHA.

Specific mortality rates for the children and adolescents younger than 15 years old were calculated and compared, ordered by sex and tumor type, and they were expressed per million inhabitants in this population. For its development, we used the average number of deaths occurred in the 2006-2008 three year period as per the vital statistics databases provided by the DEIS. ${ }^{6}$ Data for the 0-14 year old population were obtained from estimates made by the INDEC, published in the 2007 vital statistics annual report. ${ }^{4}$

The classification of causes of death from malignancies was based on the International Classification of Childhood Cancer ${ }^{7}$ according to the codes of the International Classification of Diseases and Related Health Problems $10^{\text {th }}$ revision (ICD-10), ${ }^{8}$ provided by the $\mathrm{ROHA}^{9}$ leukemias, lymphomas and reticuloendothelial tumors, central nervous system tumors, neuroblastomas, retinoblastomas, soft tissue tumors, germ cell tumors, other solid tumors of specific sites, malignant tumors of ill-defined and unspecified sites.

Morbidity data used in this study were those published by the ROHA,${ }^{5}$ made up of 91 sources of data, 12 population tumor registries and 2 collaborative medical groups, who are responsible of case reporting and active followup. The ROHA team continuously collects data from the different private and public centers of Argentina where cancer care is provided to children. This way, the registry achieved a national estimated coverage of $90 \%$ between 2000 and 2009.5,9 All cases of children with malignancies, benign tumors located in the central nervous system and multisystem histiocytosis (with or without organ involvement) are included in the registry.

The specific incidence rates were calculated for children and adolescents younger than 15 years old by tumor type, expressed per million inhabitants in this age group, based on the average number of cases occurred between 2006 and 2008, and the population used for the development of mortality rates.

\section{RESULTS}

Mortality rate from tumors was 43.8 per million in children and adolescents younger than 15 years old $(3.5 \%$ of total deaths in this age group) and the incidence rate was 123.7 per million. The analysis of specific mortality rates by sex shows that mortality was higher among boys (Table 1).

Malignancies leading to the greater number of deaths in children and adolescents were leukemia (34.8\% of total deaths from neoplasms), followed by tumors in the central nervous system $(29.6 \%)$ and lymphomas (8\%). Likewise, these types of cancer are predominant in terms of incidence (Table 2).

In relation to gender, girls only have a higher specific mortality rate from retinoblastoma, kidney and germ cell tumors. Boys had higher rates for the other types of tumors (Table 1).

\section{DISCUSSION}

The process of epidemiological transition is highly heterogeneous in Latin American countries, ${ }^{10}$ which becomes apparent when analyzing the mortality rate from malignancies and the proportion of deaths among Argentinean children. Actually, when comparing the proportion of deaths from malignancies in Argentinean children with, for example, that of Colombia, the same percentage of deaths from malignancies in individuals younger than 15 years old is observed (3.5\%).

However, the mortality rate is higher among Colombian children and adolescents, both in boys (50 per million) and girls (40 per million). ${ }^{11}$

In the case of another Latin American country, Chile, the proportion of deaths in the children and adolescents younger than 15 years old is higher $(4.3 \%)$, even though the mortality rate from tumors is lower in both genders ( 35 per million). ${ }^{12}$ Such differences are based on the different stages of the epidemiological transition ${ }^{13}$ taking place in Latin America, with an expected higher proportion of deaths caused by tumors (and other noncommunicable diseases) occuring in the more advanced stages, accompanied with a reduction in mortality rate from these causes due to a decrease in overall mortality in this age group, as observed in developed countries. ${ }^{14,15}$

In relation to mortality by malignancy type, the most frequent was leukemia. The values in this study are higher than those reported in the USA, where mortality from leukemia in 2004 accounted for $25.5 \%$ of total cancer deaths in children and adolescents younger than 15 years old. ${ }^{16}$ Likewise, mortality rate from leukemias in children and adolescents younger than 15 years old was higher than that in other developed countries.,15

However, the proportion of deaths from leukemia was lower than that reported in a 
TABLE 1. Deaths, average number of deaths and specific mortality rate from tumors, according to tumor type and gender, in children and adolescents younger than 15 years old. Argentina. 2006-2008

\begin{tabular}{|c|c|c|c|c|c|c|c|c|c|}
\hline \multirow[t]{2}{*}{ Type of tumor } & \multicolumn{3}{|c|}{$\begin{array}{l}\text { Number of deaths in the } \\
2006-2008 \text { three year period }\end{array}$} & \multicolumn{3}{|c|}{$\begin{array}{l}\text { Average number of deaths } \\
\text { 2006-2008 } \\
\end{array}$} & \multicolumn{3}{|c|}{$\begin{array}{c}\text { Mortality rate } \\
2006-2008^{*} \\
\end{array}$} \\
\hline & B & G & $\mathrm{T}$ & B & G & $\mathbf{T}$ & B & G & $\mathbf{T}$ \\
\hline Leukemias & 253 & 213 & 466 & 84 & 71 & 155 & 15.97 & 13.88 & 14.94 \\
\hline Lymphomas & 64 & 45 & 109 & 21 & 15 & 36 & 4.04 & 2.93 & 3.49 \\
\hline $\begin{array}{l}\text { Tumors of the central } \\
\text { nervous system }\end{array}$ & 226 & 169 & 395 & 75 & 56 & 132 & 14.26 & 11.01 & 12.66 \\
\hline Neuroblastoma & 38 & 20 & 58 & 13 & 7 & 19 & 2.40 & 1.30 & 1.86 \\
\hline Retinoblastoma & 3 & 8 & 11 & 1 & 3 & 4 & 0.19 & 0.52 & 0.35 \\
\hline Renal tumors & 17 & 21 & 38 & 6 & 7 & 13 & 1.07 & 1.37 & 1.22 \\
\hline Liver tumors & 18 & 9 & 27 & 6 & 3 & 9 & 1.14 & 0.59 & 0.87 \\
\hline Bone tumors & 30 & 27 & 57 & 10 & 9 & 19 & 1.89 & 1.76 & 1.83 \\
\hline Soft tissue tumors & 24 & 10 & 34 & 8 & 3 & 11 & 1.51 & 0.65 & 1.09 \\
\hline Germ cell tumors & 3 & 5 & 8 & 1 & 2 & 3 & 0.19 & 0.33 & 0.26 \\
\hline $\begin{array}{l}\text { Other solid tumors } \\
\text { in specific sites }\end{array}$ & 44 & 35 & 79 & 15 & 12 & 26 & 2.78 & 2.28 & 2.53 \\
\hline $\begin{array}{l}\text { Malignant tumors of } \\
\text { ill-defined and unspecified sites }\end{array}$ & 30 & 26 & 56 & 10 & 9 & 19 & 1.89 & 1.69 & 1.80 \\
\hline Total & 750 & 588 & 1338 & 250 & 196 & 446 & 47.33 & 38.31 & 42.89 \\
\hline
\end{tabular}

$\left(^{*}\right)$ Mortality rate expressed per 1000000 inhabitants younger than 15 years old.

Abbreviations: $\mathrm{B}=$ boys, $\mathrm{G}=$ girls, $\mathrm{T}=$ total (both genders).

Population: girls $=5003$ 826, boys $=5175$ 231. Population estimated as of June 30th, 2007 by INDEC, published in the DEISVital Statistics annual reports. Basic information. Series 5, number 51.

Source: Developed based on data provided by the Statistics and Health Information Department of the Ministry of Health of Argentina. 2000-2008.

TABLE 2. Number of cases, average number in the three year period and incidence rate of the most common malignancies in children and adolescents younger than 15 years old. Both genders. Argentina. 2006-2008

\begin{tabular}{lccccc}
\hline Type of tumor & $\mathbf{2 0 0 6}$ & $\mathbf{2 0 0 7}$ & $\mathbf{2 0 0 8}$ & Average for 2006-2008 & Incidence rate $\left.\mathbf{( *}^{*}\right)$ \\
\hline Leukemias & 460 & 473 & 448 & 460 & $\mathbf{1 5}$ \\
Lymphomas & 163 & 170 & 141 & & 15.52 \\
Tumors of the central & & & & 233 & 22.92 \\
nervous system & 243 & 214 & 243 & 71 & 6.94 \\
Neuroblastoma & 61 & 82 & 69 & 47 & 4.58 \\
Retinoblastoma & 52 & 50 & 38 & 62 & 6.12 \\
Renal tumors & 64 & 58 & 65 & 18 & 1.77 \\
Liver tumors & 20 & 13 & 21 & 56 & 5.53 \\
Bone tumors & 46 & 58 & 65 & 78 & 7.66 \\
Soft tissue tumors & 74 & 81 & 79 & 44 & 4.32 \\
Germ cell tumors & 34 & 54 & 44 & & \\
\hline
\end{tabular}

(*) Incidence rate expressed per 1000000 inhabitants younger than 15 years old.

Population: 10179 057. Population estimated as of June 30th, 2007 by INDEC, published in the DEIS-

Vital Statistics. Basic information. Series 5, number 51.

Source: Developed based on data provided by the Statistics and Health Information Department of the Ministry of Health of Argentina, 2000-2008. 
Colombian study, where mortality from leukemia accounted for $48.6 \%$ of total deaths from malignancies, and its corresponding mortality rate (2005-2008) was 22.1 per million. ${ }^{11}$

The second type of tumor with a high mortality rate was the category tumors of the central nervous system. The proportion of deaths from tumors of the central nervous system is slightly higher than in developed countries, like USA $^{16}(25 \%)$ or Ireland ${ }^{17}(27 \%)$, and much higher than in Colombia ${ }^{11}(16 \%)$. Also, mortality rate from tumors of the central nervous system in Argentinean children and adolescents was higher than that observed in developed countries such as Japan, Canada, United States of America, Italy and the United Kingdom, and lower than the rate reported in New Zealand for the 2000 decade. ${ }^{15}$

As in other studies, boys had a higher mortality rate from leukemia and tumors of the central nervous system than girls. ${ }^{11,14-17}$ It is worth noting that, although in this study the incidence of childhood tumors by sex was not analyzed because no broken-down data were available, the ROHA publishes the male/female case ratio, indicating that most tumors, except for certain of the genitourinary tissues (germ cells), girls have a lower proportion of cases. ${ }^{5}$ This is consistent with the findings in other studies ${ }^{2,18}$ and would indicate that boys have a higher risk of developing cancer.

The incidence rate of tumors is similar to that observed in countries like Uruguay and Ecuador, ${ }^{5}$ and is lower than that reported in North America and Western Europe. ${ }^{19,20}$

In relation to the incidence by tumor type, the incidence rate of leukemia is similar to that observed in Uruguay (44.0 per million) and in some developed countries, such as the USA (46.9 per million) and Spain (45.1 per million), ${ }^{5}$ and lower than other Latin American countries, e.g., Mexico ${ }^{21}$ (58 per million) and Costa Rica ${ }^{22}$ (63 per million).

Regarding the incidence of tumors of the central nervous system in the USA Hispanic children and adolescents younger than 15 years old values observed are similar to those in this study (27 per million), while higher values are observed in the non-Hispanic white population (37 per million). ${ }^{23}$ Likewise, higher values are also observed in developed countries such as Sweden (42 per million) ${ }^{24}$ while in developing countries such as Costa Rica the rate is lower (15 per million $)^{25}$ versus that of Argentinean children and adolescents.

It is worth pointing out that, in this study, no incidence rates have been observed of tumors or tumor types having unexpected values compared to those in other countries, ${ }^{5,23}$ thus indicating that Argentinean children and adolescents do not have a higher exposure to genetic or environmental carcinogens.

Among the limitations of this study the level of coverage of the death registry and the oncopediatric registry should be considered. Argentina is part of the group of Latin American and the Caribbean countries with less than $10 \%$ of mortality under-recording, ${ }^{26}$ however, such underrecording is still high in certain jurisdictions. ${ }^{27}$ Besides, the quality of the information presented in the death statistics report and the statement of the age of the deceased individual and his/her place of residence should be taken into account; a special reference should be made to the primary cause of death. ${ }^{28}$

It should be noted that Argentina is one of the few Latin American countries that records the incidence of childhood cancer, with a high level of coverage achieved through the ROHA,;,9 therefore, it is estimated that its data constitute an adequate representation of childhood cancer morbidity among Argentinean children and adolescents.

Another limitation was the lack of data regarding the prevalence of tumors in Argentinean children and adolescents, which would have enabled an estimation of case fatality rate. This rate would have been useful to determine the severity of each group of tumors and complete the morbidity and mortality analysis.

Our conclusion is that mortality from tumors in children and adolescents younger than 15 years old (43.8 per million) and the incidence rate (123.7 per million) are similar to those observed in other Latin American countries. Mortality and incidence behaviour of the main groups of tumors (leukemia, tumors of the central nervous system) would indicate that leukemia treatment and detection is better than in other Latin American countries, given the lower mortality rate and similar incidence, but it is far from the situation in developed countries, that have lower mortality rates and similar incidence rates. As far as tumors of the central nervous system, mortality rates are similar and even higher than those in developed countries, in spite of a lower incidence rate. This indicates that it is necessary to devote more effort to their early detection and effective treatment in Argentinean children and adolescents. 


\section{REFERENCES}

1. Vargas L. Cáncer en pediatría: Aspectos generales. Rev Chil Pediatr 2000; 71: 283-95.

2. Fajardo-Gutiérrez A, Mejía-Aranguré JM,Hernández-Cruz L,Mendoza-Sánchez HF, et al. Epidemiología descriptiva de las neoplasias malignas en niños. Rev Panam Salud Pública 1999; 6:75-88.

3. La Vecchia C, Levi F, Lucchini F, Lagiou P, et al. Trends in childhood cancer mortality as indicators of the quality of medical care in the developed world. Cancer 1998; 83:2223-7.

4. Ministerio de Salud de la Argentina. Dirección de Estadísticas e Información en Salud. Estadísticas Vitales-Información básica 2007. Serie 5 - Número 51. Buenos Aires.2008. [Acceso: 9 de julio de 2011]. Disponible: http:/ / www.deis.gov.ar/Publicaciones / Archivos / Serie5Nro51.pdf.

5. Moreno F, Schvartzman E. Registro Oncopediátrico Hospitalario Argentino (ROHA), Resultado 2000-2008. Buenos Aires: Fundación Kaleidos. 2010. [Acceso: 20 de julio de 2011]. Disponible en://www. fundacionkaleidos. org/Roha_publicaciones/roha2008. pdf.

6. Dirección de Estadísticas e Investigación en Salud: Base de datos de defunciones en Argentina 2006-2008. [CD-ROM]. Buenos Aires: DEIS; 2010. 1 CD-ROM.

7. Steliarova-Foucher E, Stiller C, Lacour B, Kaatsch P. International Classification of Childhood Cancer Third Edition (ICCC-3- based on ICD-O-3) Cancer 2005;103:1457-67.

8. Organización Mundial de la Salud. Clasificación Internacional de las Enfermedades. Décima Edición. Ginebra: Organización Mundial de la Salud; 1992.

9. MorenoF, Dussel V, Abriata G, Loria D, Orrellana L. Registro Oncopediátrico Hospitalario Argentino: incidencia 20002009 supervivencia 2000-2007 tendencia de mortalidad 1997-2010. 1a ed. Buenos Aires: Instituto Nacional del Cáncer, 2012.

10. Di Cesare, M. El perfil epidemiológico de América Latina y el Caribe: Desafíos límites y acciones. Santiago de Chile: Naciones Unidas; 2011.

11. Piñeros M, Gamboa O, Suárez A. Mortalidad por cáncer infantil en Colombia durante 1985 a 2008. Rev Panam Salud Pública 2011;30:15-21.

12. CerdaJ, Romero MI, WietstruckMA. Mortalidad por cáncer infantil en Chile. Modelo de transición epidemiológica en la infancia. Rev Chil Pediatr 2008;79:481-7.

13. Chackiel J. La dinámica demográfica en América Latina. Santiago de Chile: CEPAL Centro Latinoamericano y Caribeño de Demografía (CELADE). División de Población y Desarrollo. 2004;44.
14. Planificación Sanitaria. La situación del cáncer en España. Madrid: Ministerio de Sanidad y Consumo. 2005; 89.

15. Yang L, Fujimoto J, Qui D, Sakamoto M. Childhood cancer in Japan: focusing on trend in mortality from 1970 to 2006. Ann Oncol 2009; 20: 166-74.

16. Centers for Disease Control and Prevention (CDC). Trends in childhood cancer mortality. United States, 1990-2004. Morb Mortal Wkly Rep 2007; 56:1257-61.

17. Stack M, Walsh PM, Comber H, Ryan CA, et al. Childhood cancer in Ireland: a population-based study. Arch Dis Child 2007; 92: 890-7.

18. González García H, Blanco Quirós A, Valbuena Crespo C, Gutiérrez Meléndez P, et al. Incidencia del cáncer infantil en la Comunidad de Castilla y León(2003-2007). An Pediatr 2010;73:169-79.

19. Moreno F, Loria D, Abriata G, Terracini B, ROHAnetwork, Childhood cancer: Incidence and early deaths in Argentina, 2000-2008. Eur J Cancer 2013 Jan;49(2):465-73.

20. Abriata MG, Moreno F. Cáncer en la población de menores de 15 años en Argentina. Rev Argent Salud Pública 2010; 1(3):42-5.

21. Pérez-Saldivar ML, Fajardo-Gutiérrez A, Bernáldez-Ríos R, Martínez-Avalos A, et al. Childhood acute leukemias are frequent in Mexico City: descriptive epidemiology. BMC Cancer 2011; 17(11):355.

22. Monge $\mathrm{P}$, Wesseling $\mathrm{C}$, Rodríguez AC, Cantor $\mathrm{K}$ et al. Childhood leukemia in Costa Rica, 1981-1996. Paediatr Perinatal Epidemiol 2002;16:210-8.

23. American Cancer Society. Datos y Estadísticas sobre el cáncer entre los hispanos/latinos 2012-2014. Atlanta: Sociedad Americana contra el cáncer; 2012.

24. Lannering B, Sandstróm PE, Holm S, Lundgren J et al. Classification, incidence and survival analyses of children with CNS tumours diagnosed in Sweden 1984-2005. Acta Paediatr 2009; 98(10):1620-7.

25. Reutfors J, Kramárová E, Weiderpass E, Monge P et al. Central nervous system tumours in children in Costa Rica, 1981-96. Paeditr Perinat Epidemiol 2002;16(3):219-25.

26. Bay G, Orellana H. La calidad de las estadísticas vitales en la América Latina. Taller de expertos en el uso de estadísticas vitales: alcances y limitaciones. Versión preliminar para discusión. Santiago de Chile, Chile: CEPAL-UNFPA-OPS; 2007.

27. Fernández M, Gevel C, Krupizki H, Marconi E, Casas C. Omisión de registro de nacimientos y muertes infantiles: magnitud, desigualdades y causas. Buenos Aires: Organización Panamericana de la Salud. Ministerio de Salud; 2008.

28. World Health Organization. Strengthening civil registration and vital statistics for births, deaths and causes of death: resource kit. Luxembourg: World Health Organization;2013. 